\title{
Electrophoretic Analysis of Proteins from Mycoplasma hominis Strains Detected by SDS-PAGE, Two-dimensional Gel Electrophoresis and Immunoblotting
}

\author{
By HANS ANDERSEN,* SVEND BIRKELUND, GUNNA CHRISTIANSEN \\ AND EYVIND A. FREUNDT \\ Institute of Medical Microbiology, Bartholin Building, University of Aarhus, DK-8000 Aarhus C, \\ Denmark
}

(Received 1 November 1985; revised 12 May 1986)

\begin{abstract}
The proteins of 14 strains of Mycoplasma hominis were compared by SDS-PAGE in gradient gels, by two-dimensional (2D) gel electrophoresis of extracts of ${ }^{35} \mathrm{~S}$-labelled cells and by immunoblot analysis of cell proteins. The strains examined included the $M$. hominis type strain PG21 and 13 others isolated variously from genital tract, mouth, blood, upper urinary tract and a wound. These 14 strains shared $76-99 \%$ of proteins in SDS-gradient gel analysis and $41-72 \%$ in the 2D gels. As expected, the immunoblot analysis likewise revealed the existence of an extensive common protein pattern in $M$. hominis, in addition to a number of antigens shared only by some strains.
\end{abstract}

\section{INTRODUCTION}

There are 12 species of the class Mollicutes currently recognized as occurring in man, four of which are associated with the genital tract - Mycoplasma hominis, Mycoplasma fermentans, Mycoplasma genitalium and Ureaplasma urealyticum. M. hominis is commonly found in the female genital tract and several epidemiological, microbiological, serological and animal model studies have shown that it is potentially pathogenic and may be involved in, for example, acute pelvic inflammatory disease (Taylor-Robinson \& McCormack, 1980), acute pyelonephritis (Thomsen, 1978) and postpartum fever (Platt et al., 1980). However, assessment of the pathogenic potential of $M$. hominis is complicated by the fact that this species constitutes a relatively heterogeneous group of organisms. Serologically, significant antigenic differences have been demonstrated by tube agglutination (Nicol \& Edward, 1953), indirect haemagglutination (IHA) (Taylor-Robinson et al., 1965; Hollingdale \& Lemcke, 1970; Thomsen, 1978), metabolism inhibition (MI) (Purcell et al., 1967; Hollingdale \& Lemcke, 1970; Lin \& Kass, 1974; Thomsen, 1978) and a complement-dependent mycoplasmacidal test (MC) (Lin \& Kass, 1974). By growth inhibition (GI) intraspecific differences were found by Razin (1968) and Lin et al. (1975), but not by Hollingdale \& Lemcke (1970). Unpublished studies in our laboratory did not reveal any intraspecific heterogeneity by GI, whereas various degrees of cross-reactivity between a total of $14 \mathrm{M}$. hominis strains (those examined in the present study) were obtained by IHA, MI and MC tests. In complement fixation (CF) tests, little difference between strains was found by Hollingdale \& Lemcke (1970). Razin (1968) and Hollingdale \& Lemcke (1970) found dissimilarities in the protein patterns of different $\boldsymbol{M}$. hominis strains by PAGE. Genetic heterogeneity within the species has been demonstrated by nucleic acid hybridization studies (e.g. Somerson et al., 1966; Barile et al., 1983).

\footnotetext{
Abbreviations: 2D, two-dimensional; CF, complement fixation; GI, growth inhibition; IHA, indirect haemagglutination; MC, mycoplasmacidal; MI, metabolism inhibition.
} 
The objective of the present investigation was to determine whether this reported intraspecific heterogeneity of $M$. hominis could be confirmed and analysed by examining the protein patterns of 14 strains, using SDS-PAGE, two-dimensional (2D) gel electrophoresis and immunoblotting. The 2D gel electrophoresis technique was included because of its known usefulness in detecting differences in protein patterns between relatively closely related mycoplasmas (Rodwell \& Rodwell, 1978; Mouches et al., 1979; Rodwell, 1982; Andersen et al., 1984; Nascimento et al., 1986).

\section{METHODS}

Strains and cultivation. The source and origin of the 14 strains of $M$. hominis investigated are shown in Table 1 . The strains include several extensively analysed by others (for references see Table 1). All strains were subcloned by filter $(450 \mathrm{~nm}$ ) cloning in the approved manner (International Committee on Systematic Bacteriology Subcommittee on the Taxonomy of Mollicutes, 1979). Their identity as $M$. hominis was confirmed serologically by growth inhibition, metabolism inhibition, indirect immunofluorescence and indirect haemagglutination tests.

Media. The mycoplasma strains, which are arginine-metabolizing and glucose-nonfermenting, were cultivated in a medium (BEA) supplemented with arginine and composed of heart infusion broth (Difco), $2 \cdot 2 \%(\mathrm{w} / \mathrm{v}) ;$ horse serum, $15.5 \%(\mathrm{v} / \mathrm{v})$; fresh yeast extract (Hayflick, 1965), $1.9 \%(\mathrm{w} / \mathrm{v})$; thallium acetate, $0.008 \%$; benzylpenicillin, 40 i.u. $\mathrm{ml}^{-1} ; \mathrm{L}$-arginine, $0.23 \%(\mathrm{w} / \mathrm{v})$ and phenol red, $0.0023 \%(\mathrm{w} / \mathrm{v})$. The $\mathrm{pH}$ was adjusted to $7 \cdot 2$ and the medium sterilized by filtration.

SDS-PAGE of cell proteins. The mycoplasmas, unlabelled or labelled with $\left[{ }^{35} S\right]$ methionine, were freeze-thawed four times, resuspended in SDS sample buffer $(0.0625 \mathrm{M}-\mathrm{Tris} / \mathrm{HCl} \mathrm{pH} 6.8,2.3 \%(\mathrm{w} / \mathrm{v}) \mathrm{SDS}, 5 \%(\mathrm{v} / \mathrm{v}) 2-$ mercaptoethanol, $10 \%$ (v/v) glycerol, $0.05 \%$ bromophenol blue), and heated to $100{ }^{\circ} \mathrm{C}$ for $2 \mathrm{~min}$. Insoluble material was removed by centrifugation $(2 \mathrm{~min}$ at $10000 \mathrm{~g}$ ) in a microcentrifuge before electrophoresis was carried out in a $12-20 \%(\mathrm{w} / \mathrm{v})$ polyacrylamide gradient gel. Samples $(5-30 \mu \mathrm{l})$ containing about 30000 c.p.m. were applied to the gels. For unlabelled samples, the protein bands were visualized by Coomassie blue staining.

$2 D$ gel electrophoresis of cell proteins. The $\left[{ }^{35} \mathrm{~S}\right]$ methionine-labelled mycoplasmas were freeze-thawed four times and resuspended in lysis buffer as previously described (Andersen et al., 1984). Samples containing 50000 c.p.m. were applied to a cylindrical pH 5-7.5 isoelectric focusing gel $(165 \times 2 \mathrm{~mm})$ for separating acidic proteins (O'Farrell, 1975). The gels were run for $18 \mathrm{~h}$ at $400 \mathrm{~V}$ followed by electrophoresis in the second dimension (Laemmli, 1970). $M_{\mathrm{r}}$ standards used in the second-dimension SDS-slab gel electrophoresis were $\left[{ }^{14} \mathrm{C}\right]$ methylated proteins (Amersham).

Measurement of the $\mathrm{pH}$ gradient in isoelectric focusing gels. One of the isoelectric focusing gels was cut into $5 \mathrm{~mm}$ slices and placed in $1 \mathrm{ml} 0.1 \mathrm{M}-\mathrm{KCl}$, and the $\mathrm{pH}$ was measured after the gel slices had been eluted (Archer et al., 1978).

Preparation of rabbit hyperimmune serum. The antigens used for immunization of rabbits were prepared from organisms grown in rabbit-meat infusion broth and rabbit serum. (Taylor-Robinson et al., 1963). Mycoplasma cultures grown in $600 \mathrm{ml}$ RE-medium (Ernø et al., 1973), supplemented with $1 \%$ (v/v) PPLO serum fraction (Difco) were harvested in the exponential phase, by centrifugation at $38000 \mathrm{~g}$ for $1 \mathrm{~h}$, washed twice in PBS buffer (12 mM-sodium phosphate, $0.145 \mathrm{M}$-sodium chloride, $\mathrm{pH} 7 \cdot 0$ ), and resuspended in $24 \mathrm{ml} \mathrm{PBS}$. After sonication (Branson sonifier B-12; $1 \mathrm{~min}$ at $40 \mathrm{~W}$ ) the antigen was stored in $1 \mathrm{ml}$ volumes at $-20^{\circ} \mathrm{C}$. Two rabbits were inoculated intramuscularly twice a week, for three weeks, with a mixture of equal volumes $(0.75 \mathrm{ml})$ of antigen and Freund's complete adjuvant. Three weeks later they were given three injections (every second day) of antigen $(1.5 \mathrm{ml})$ in the marginal ear vein. Two to four weeks after the last injection, blood was obtained and tested for reactivity by immunofluorescence. The rabbits were killed by exsanguination and the sera stored in $5 \mathrm{ml}$ volumes at $-20^{\circ} \mathrm{C}$. Preimmunization sera were obtained from all the rabbits and included as controls in every test.

Immunoblotting. SDS-PAGE for immunoblotting was done using the discontinuous buffer system (Laemmli, 1970) in a Bio-Rad protein dual-slab cell. Mycoplasma proteins, prepared as described for SDS-PAGE, were applied (approx. $5 \mu \mathrm{g}$ protein per track) to a $10 \%(\mathrm{w} / \mathrm{v})$ polyacrylamide gel (final dimensions $160 \times 130 \times 0.8 \mathrm{~mm}$ ). Proteins were transferred from the SDS-PAGE slab gel to nitrocellulose membranes (Schleicher \& Schuell BA-85, pore size $0.45 \mu \mathrm{m}$ ) by means of a Bio-Rad trans-blot cell. The electrode buffer (transfer buffer) was $0.025 \mathrm{M}$-Tris, $0.192 \mathrm{M}$-glycine $\left(\mathrm{pH} 8 \cdot 3\right.$ ). A voltage of $15 \mathrm{~V} \mathrm{~cm}^{-1}$ was applied for $4 \mathrm{~h}$ (current $0.34-0.75 \mathrm{~A}$ ). The temperature was kept between $4{ }^{\circ} \mathrm{C}$ and $8^{\circ} \mathrm{C}$. Two different methods were used to detect antigens transferred to nitrocellulose.

Method (1) (Bjerrum et al., 1983). After transfer, the remaining sites for protein binding were blocked by incubating the nitrocellulose blots for $2 \mathrm{~min}$ at room temperature in TBS buffer $(50 \mathrm{~mm}$-Tris, $150 \mathrm{~mm}-\mathrm{NaCl}, 2 \%$, $\mathrm{w} / \mathrm{v}$, Tween $20, \mathrm{pH} \mathrm{10} 2)$. The blots were then washed three times in TTBS buffer $(50 \mathrm{mM}$-Tris, $150 \mathrm{mM}-\mathrm{NaCl}$, $0.05 \%, \mathrm{w} / \mathrm{v}$, Tween $20, \mathrm{pH} 10 \cdot 2$ ), in order to remove excess blocking agent, before incubation with gentle rocking for $30 \mathrm{~min}$ at $37^{\circ} \mathrm{C}$ with primary antibody (rabbit antiserum) diluted 1 in 100 in TTBS buffer. Unbound antibody was removed by washing the blots three times for $10 \mathrm{~min}$ in TTBS. Incubation with secondary antibody (goat anti- 
Table 1. Mycoplasma hominis strains and their origin

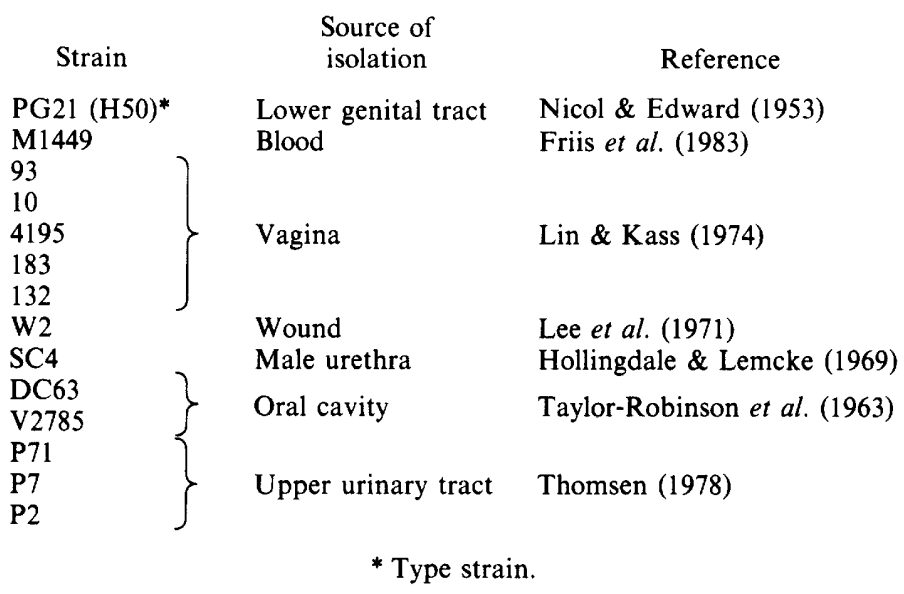

rabbit immunoglobulin-peroxidase conjugated, Bio-Rad) was performed as described above, but with a working dilution of 1 in 3000 . The blots were washed again and then immersed in a freshly prepared staining solution

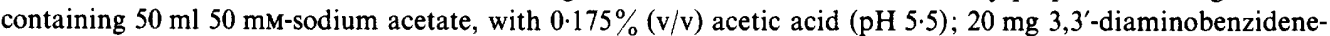
tetrahydrochloride (peroxidase substrate) and $25 \mu 1 \mathrm{H}_{2} \mathrm{O}_{2}(30 \%, \mathrm{w} / \mathrm{v})$. The staining was complete within 1-5 min. The developed blots were washed in distilled water for $10 \mathrm{~min}$ and incubated in $50 \mathrm{~mm}$-sodium disulphite for another $5 \mathrm{~min}$. The blots were then dried.

Method (2) (Bio-Rad Instruction Manual). Blocking was effected by treatment for 10 min at $37{ }^{\circ} \mathrm{C}$ with $3 \%$ $(\mathrm{w} / \mathrm{v})$ gelatin, $20 \mathrm{~mm}$-Tris, $500 \mathrm{~mm}-\mathrm{NaCl}, \mathrm{pH} 7 \cdot 5$. The blots were washed three times in $20 \mathrm{~mm}$-Tris, $500 \mathrm{~mm}-\mathrm{NaCl}$, $0.05 \%, \mathrm{w} / \mathrm{v}$, Tween 20, pH 7.5. Primary antibody, diluted 1 in $50 \mathrm{in} 1 \%(\mathrm{w} / \mathrm{v})$ gelatin in $20 \mathrm{mM}-\mathrm{Tris}, 500 \mathrm{mM}-\mathrm{NaCl}$, $\mathrm{pH} 7.5$, was applied and the test incubated at $37^{\circ} \mathrm{C}$ for $1 \mathrm{~h}$. Washing was done as previously indicated. The secondary antibody was applied at a dilution of 1 in 3000 in the same buffer as for primary antibody, and incubated at $37^{\circ} \mathrm{C}$ for $1 \mathrm{~h}$. The blots were washed as before but with one additional washing in $20 \mathrm{mM}$ - Tris, $500 \mathrm{mM}-\mathrm{NaCl}$, $\mathrm{pH} 7.5$, because Tween 20 interferes with the staining reaction using 4-chloro-1-naphthol. The staining solution was $20 \mathrm{mM}$-Tris, $500 \mathrm{mM}-\mathrm{NaCl}, 17 \%(\mathrm{v} / \mathrm{v})$ methanol, $0.4 \mathrm{mg}$ 4-chloro-1-naphthol $\mathrm{ml}^{-1}$; staining was complete within $15-30 \mathrm{~min}$. The blots were washed in distilled water and dried.

\section{RESULTS}

The proteins of the $14 \mathrm{M}$. hominis strains proved very similar when analysed in SDS-gradient gels. At least 70 distinct protein bands were seen in autoradiograms as well as by staining of unlabelled proteins with Coomassie blue. A comparative analysis of the protein bands obtained with the 14 strains revealed very similar electrophoretic patterns, with similarities between $76 \%$ and $99 \%$ congruence. The results obtained for some of the strains are shown in Fig. $1(a)$, including the two most similar strains (DC63 and 132, with $99 \%$ congruence) and the two most different strains (P7 and V2785, with $76 \%$ congruence). In spite of the high similarity values, it was possible to distinguish each of the 14 strains on the basis of small differences in the protein patterns, as demonstrated in Fig. $1(b)$, showing, for four strains, an enlarged segment of the autoradiogram in Fig. 1(a). Dissimilar bands in the 14 strains were most evident in the $M_{\mathrm{r}}$ $35000,44000,78000$ and 106000 regions. Comparative gradient gel analysis between the type strain PG21 and the other $13 \mathrm{M}$. hominis strains showed $78-87 \%$ congruence.

Autoradiograms of the 2D gels from the $14 \mathrm{M}$. hominis strains were exposed for about four weeks. Between 54 and 94 acidic proteins were detected in each autoradiogram and further exposure revealed no more. The basis for comparisons of the autoradiograms was $M_{\mathrm{r}}$ standards in the second dimension and determination of the $\mathrm{pH}$ gradient in the focusing dimension. Each autoradiogram was divided into squares according to specific $\mathrm{pH}$ and $M_{\mathrm{r}}$ values as previously described (Andersen et al., 1984). The electrophoretic 2D protein patterns of the $14 \mathrm{M}$. hominis strains had similarities between individuals ranging from $41 \%$ to $72 \%$ (Table 2 ) as derived from the number of common protein spots and calculated from the formula previously described 
(a)

(b)

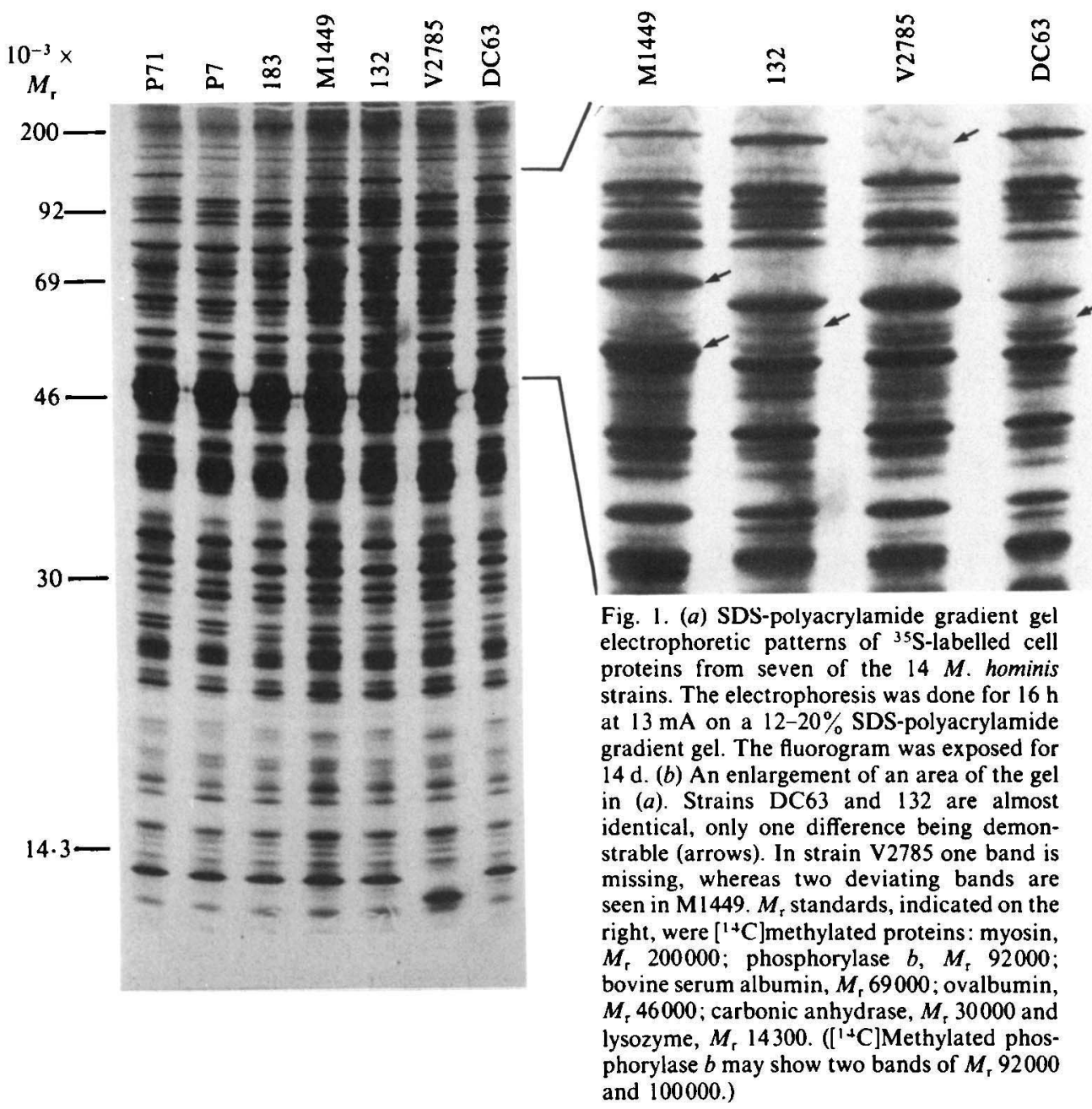

(Rodwell \& Rodwell, 1978; Rodwell, 1982; Andersen et al., 1984). Most proteins were localized around pH 5-7 with $M_{\mathrm{r}}$ values between 30000 and 100000 . When the 2D gels were compared, common proteins among all $14 \mathrm{M}$. hominis strains were found mainly in the $M_{\mathrm{r}}$ range 25000 60000 . Thirty-two of the quantitatively most prominent protein spots, all present in strain PG21 (Fig. $2 a$ ), were selected for a gel spot comparison. Sixteen of these selected proteins were shared by all the strains. The results of the comparisons are shown in Table 3 . An example of the gel spot comparison is given in Fig. 2(b), showing proteins common to strains P71 and PG21. Thirty-eight of the protein spots were shared by the two strains and the calculated percentage congruence was $58 \%$ (Table 2 ).

Heterogeneity of immunogens was studied by two different immunoblot analyses. Coomassie blue stained SDS-PAGE patterns of cell proteins from the $14 \mathrm{M}$. hominis strains showed between 45 and 55 separate bands (Fig. 3), of $M_{\mathrm{r}}$ 19000-200000. By the first immunoblot analysis (Bjerrum et al., 1983), proteins from all 14 strains were transferred to nitrocellulose and tested against each of the corresponding 14 rabbit hyperimmune sera. An example is shown in Fig. 4, which gives the results obtained when antiserum to strain M1449 was tested against all 14 strains. By the second immunoblot analysis (Bio-Rad), proteins from each of the 14 strains were transferred to nitrocellulose, sliced and tested against each of the 14 rabbit hyperimmune sera. The results obtained for the proteins prepared from strain DC63 are shown in Fig. 5. A complete cross-examination of the 14 strains was made twice by each method; it produced results very 


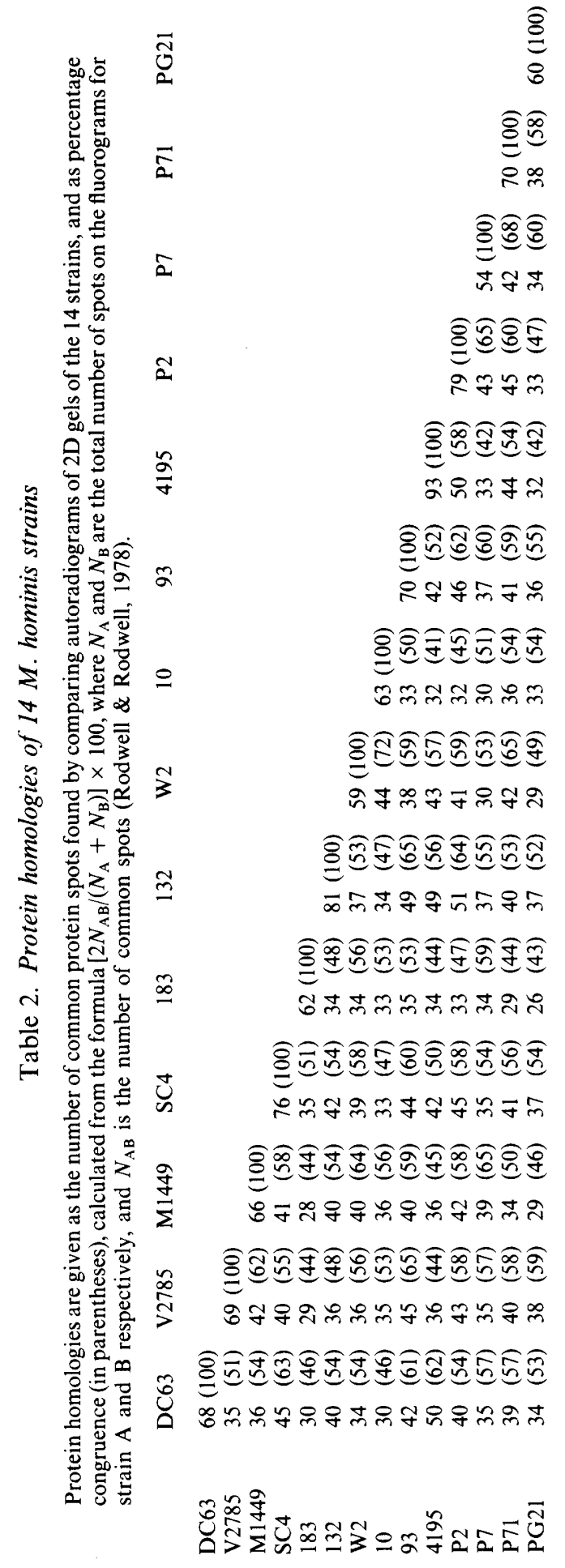



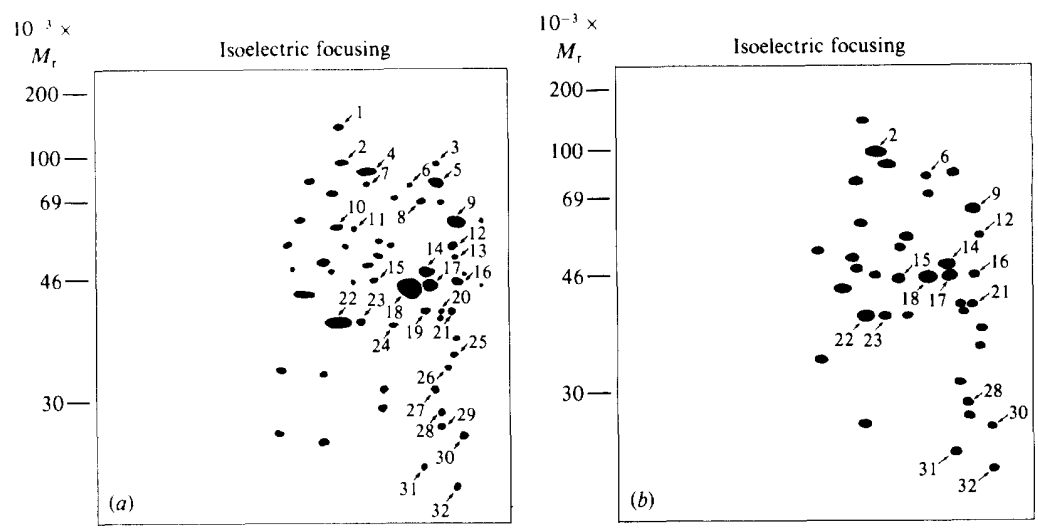

Fig. 2. (a) Diagrammatic representation of the positions of proteins as seen in $2 \mathrm{D}$ gel electrophoresis of cell proteins of $M$. hominis strain PG21 (type strain). Thirty-two of the quantitatively most prominent proteins are shown. (b) Positions of proteins common to $M$. hominis strains P71 and PG21, as seen when comparing the $2 \mathrm{D}$ electrophoretic protein patterns of cell proteins. Sixteen of the quantitatively most prominent proteins also shared by the other $12 \mathrm{M}$. hominis strains are indicated by arrows. $M_{\mathrm{r}}$ standards (see Fig. 1) are shown to the left, and the $\mathrm{pH}$ gradient is shown at the top of each diagram.

Table 3. Occurrence of proteins present in M. hominis strains as shown by $2 \mathrm{D}$ gel spot comparisons

Each column indicates the presence $(+)$ or absence $(0)$ of each of the 32 selected spots that were all present in the autoradiogram for the type strain, PG21, which was used as the standard for comparisons with that for each other strain.

PG21

spot no.

$\begin{array}{ccccccccccccccc}\text { compared* } & \text { DC63 } & \text { V2785 } & \text { M1449 } & \text { SC4 } & 183 & 132 & \text { W2 } & 10 & 93 & 4195 & \text { P2 } & \text { P7 } & \text { P71 } \\ 1 & + & + & + & + & + & + & + & 0 & + & 0 & + & 0 & + \\ 3 & + & + & + & + & + & + & + & + & + & + & + & + & 0 \\ 4 & + & + & 0 & + & + & + & + & 0 & + & + & + & + & + \\ 5 & + & 0 & 0 & + & + & 0 & + & + & + & + & 0 & 0 & 0 \\ 7 & + & + & 0 & + & + & + & + & 0 & + & + & + & + & + \\ 8 & + & + & 0 & + & 0 & 0 & 0 & 0 & + & + & + & 0 & + \\ 10 & + & 0 & + & + & + & + & + & + & + & 0 & + & + & + \\ 11 & + & 0 & + & + & + & + & + & + & + & 0 & + & + & + \\ 13 & + & 0 & 0 & 0 & 0 & 0 & 0 & 0 & 0 & 0 & 0 & 0 & 0 \\ 19 & + & + & + & + & + & + & + & + & + & + & 0 & 0 & 0 \\ 20 & + & + & + & + & + & + & + & + & + & + & 0 & 0 & + \\ 24 & + & + & + & + & + & + & + & + & + & + & + & 0 & + \\ 25 & 0 & 0 & + & + & 0 & + & + & + & + & + & + & + & + \\ 26 & 0 & + & 0 & 0 & + & 0 & 0 & 0 & 0 & 0 & + & + & 0 \\ 27 & 0 & + & 0 & + & + & + & + & + & + & + & + & + & + \\ 29 & + & + & + & + & + & + & 0 & + & + & + & + & + & +\end{array}$

* Spot numbers not listed were present in all the strains.

similar to those shown in Figs 4 and 5. Using each of the 14 rabbit hyperimmune sera it was possible to identify $20-29$ individual protein immunogens in the 14 strains, with $M_{\mathrm{r}}$ values ranging between 30000 and 100000 . Nineteen prominent proteins, indicated by numbers in Figs 3, 4 and 5, were selected for a more detailed study (Table 4). Common bands were most evident in the $M_{\mathrm{r}}$ regions 30000-39000, 44000-57000 and 92000-96000. The comparisons showed that 12 of the 19 antigens were found in all strains (Table 4). Eight of these antigens $(2,3,11,12,16$, 17,18 and 19) were recognized when testing all 14 hyperimmune sera against any of the $14 \mathrm{M}$. hominis strains with the method described by Bjerrum et al. (1983) (with the Bio-Rad method, bands 16, 17, 18 and 19 were sometimes faint or undetectable). Antigen 1 was found in all but two (V2785 and PG21) of the 14 strains. However, antiserum against each of these two strains 


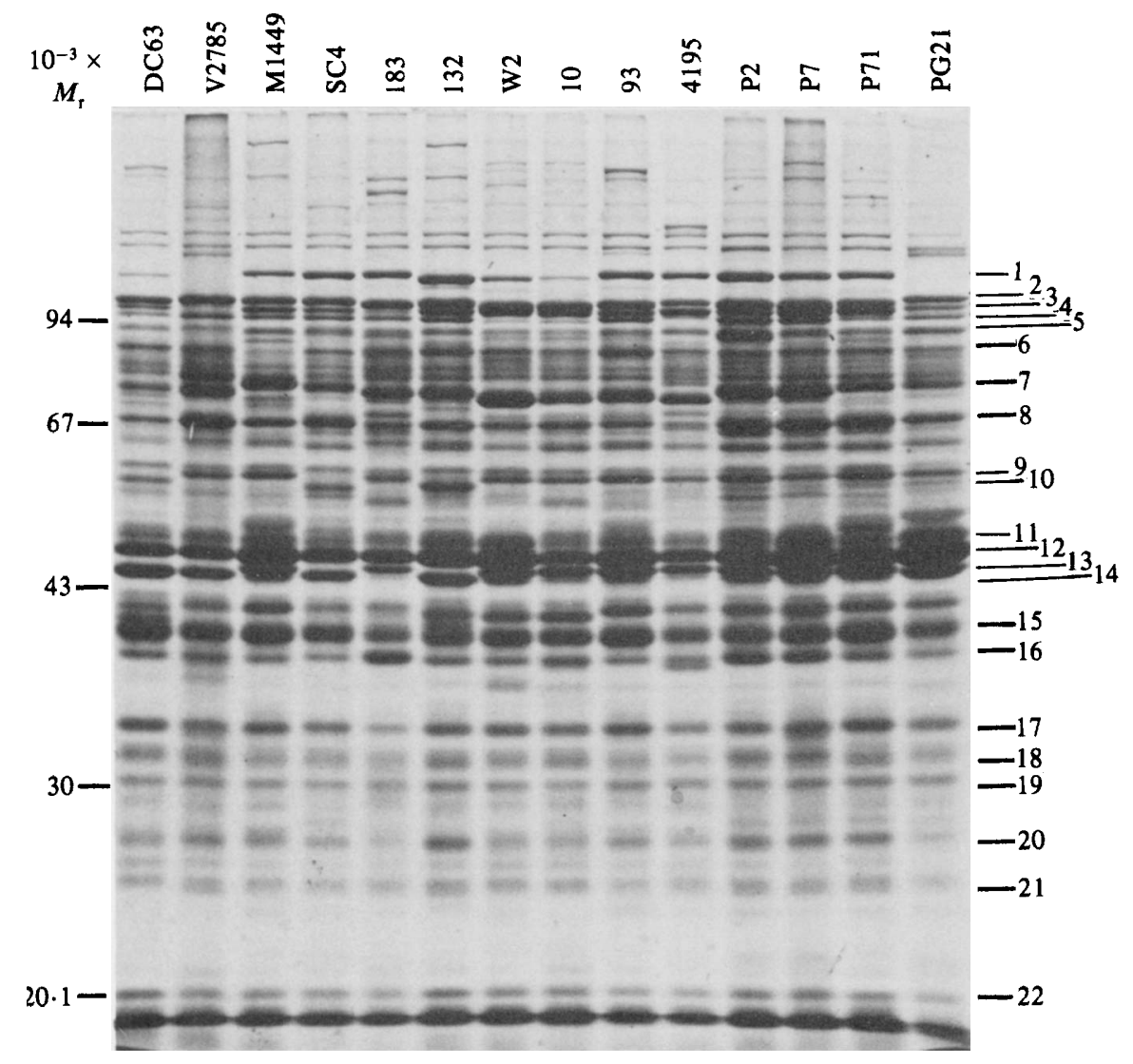

Fig. 3. SDS-PAGE patterns of cell proteins from $14 \mathrm{M}$. hominis strains. The electrophoresis was done for $16 \mathrm{~h}$ at $60 \mathrm{~V}$ on a $10 \%(\mathrm{w} / \mathrm{v})$ polyacrylamide gel. The gel was stained with Coomassie blue. The positions of the $M_{\mathrm{r}}$ standards are shown on the left. The numbers to the right indicate some proteins detected by immunoblotting analysis (Figs 4 and 5); the $M_{\mathrm{r}}$ range is from 102000 to 19000 (bands 1 and 22). $M_{\mathrm{r}}$ standards: phosphorylase $b, M_{\mathrm{r}} 94000$; bovine serum albumin, $M_{\mathrm{r}} 67000$; ovalbumin, $M_{\mathrm{r}}$ 43000 ; carbonic anhydrase, $M_{\mathrm{r}} 30000$ and soybean trypsin inhibitor, $M_{\mathrm{r}} 20100$.

did react with antigen 1 in all the other strains, except strain 10. Therefore, strains V2785 and PG21 apparently carried this antigenic determinant, but on a protein of different $M_{\mathbf{r}}$. Antigens 11,12 and $13 / 14$ were quantitatively the most dominant bands seen in SDS-PAGE, as well as in the immunoblotting with both homologous and heterologous hyperimmune sera. Seven of the 19 antigens were not found in all $14 \mathrm{M}$. hominis strains (Table 4). Antigen 14 was found only in those strains that did not have antigen 13. Therefore, these two antigens seemed to be immunologically identical and could be recognized by all $14 \mathrm{M}$. hominis strain hyperimmune sera. More complex reaction patterns were seen in the region $M_{\mathrm{r}} 70000-90000$, where the bands seemed to be very different for all 14 strains. Immunological detection of minor antigens in this region showed a greater variation than could be seen by SDS-PAGE. An example is the antigen band 6 found by SDS-PAGE in all strains. This protein was detected in immunoblotting tests by all homologous sera, but showed a marked variation with heterologous sera, which indicated that the protein was variable.

\section{DISCUSSION}

According to the definition proposed by the International Committee on Systematic Bacteriology Subcommittee on the Taxonomy of Mollicutes (1979), a mycoplasma species may, ideally, be regarded as a cluster of morphologically similar isolates that exhibit a high degree of 


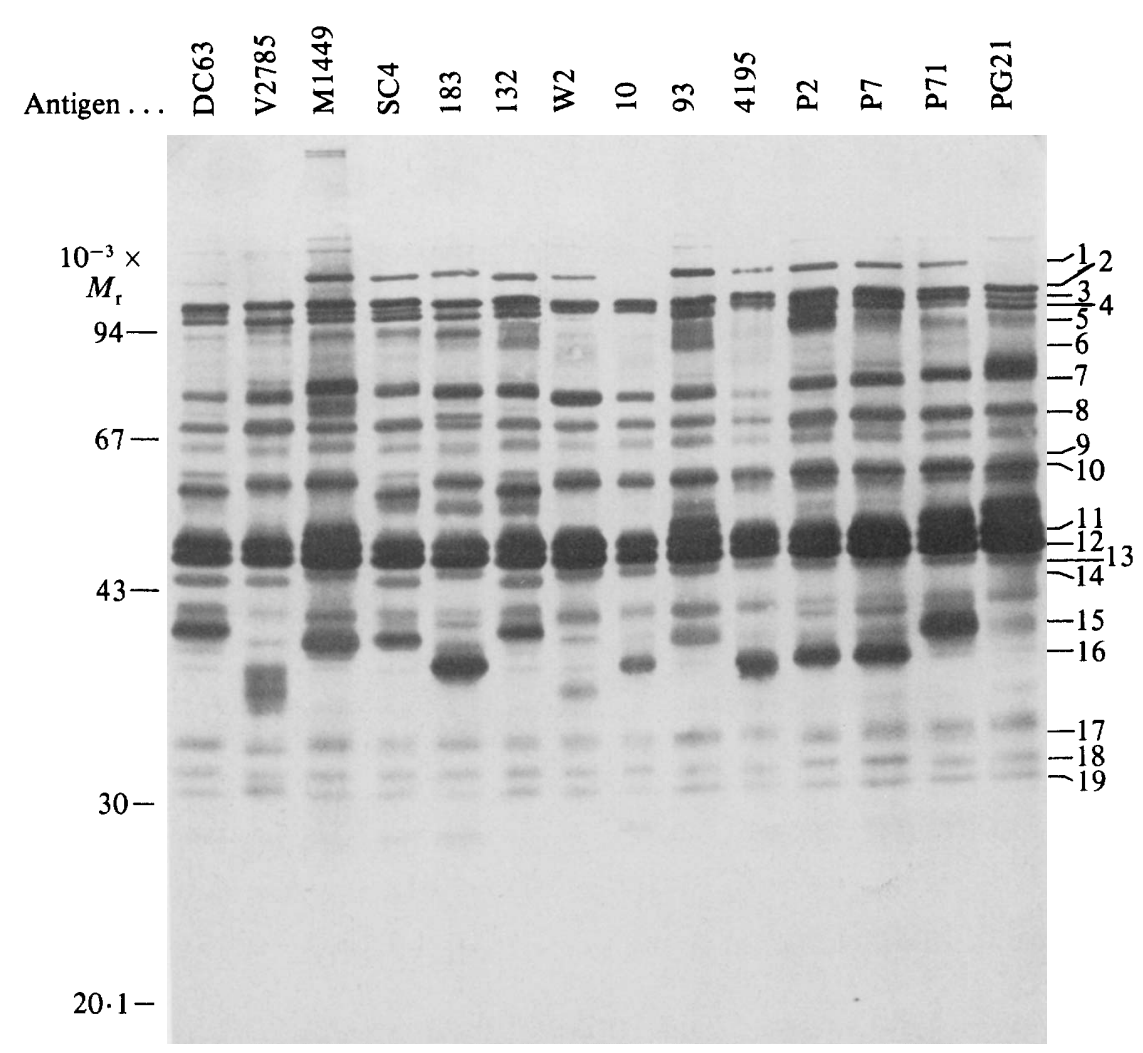

Fig. 4. Immunological identification of $M$. hominis antigens after blot transfer using a rabbit antiserum to $M$. hominis M1449. Some of the 22 protein bands selected from the SDS-gel (Fig. 3) and which were immunologically detected are shown to the right. The method used was according to Bjerrum et al. (1983). $M_{\mathrm{r}}$ standards as in Fig. 3.

genetic and phenotypic relatedness. However, the degree of intraspecific homogeneity actually found in individual species of the mollicutes varies widely. $M$. hominis is clearly among the species which exhibit particularly marked intraspecific heterogeneity (see Introduction). The complexity of the relationships based upon serological differences between strains of this species was emphasized by Hollingdale \& Lemcke (1969), who showed that antigens stimulating the development of GI, MI and IHA antibodies resided almost exclusively in the cell membrane, whereas antigens involved in the CF test were mainly associated with the cytoplasmic cell fraction.

In the following discussion of our results, it should be kept in mind that the immunizing antigens used for production of antisera were prepared from sonically disrupted mycoplasma cells. Similarly, the protein preparations used in PAGE, 2D gel electrophoresis, and immunoblotting experiments were lysates prepared from whole-cell suspensions. Hence, the results obtained do not discriminate between membraneous and cytoplasmic proteins. The two immunoblotting methods we used were chosen because they allow a direct comparative analysis of those parts of the protein patterns that are responsible for antigenic similarities and dissimilarities between different strains, as revealed by conventional serology, and these results can also be directly compared with those obtained by SDS-PAGE. All these methods have the limitation, however, that only a very minor proportion of the cell proteins is detected. For example, the number of proteins recognized by $2 \mathrm{D}$ gel electrophoresis (between 54 and 93) in different strains represents only $8-15 \%$ of that expected from the coding capacity of the genome (Andersen et al., 1984). However, it is noteworthy that the average number of 70 distinct bands demonstrated in this study by SDS-PAGE, whether in autoradiograms (Fig. 1) or by Coomassie 


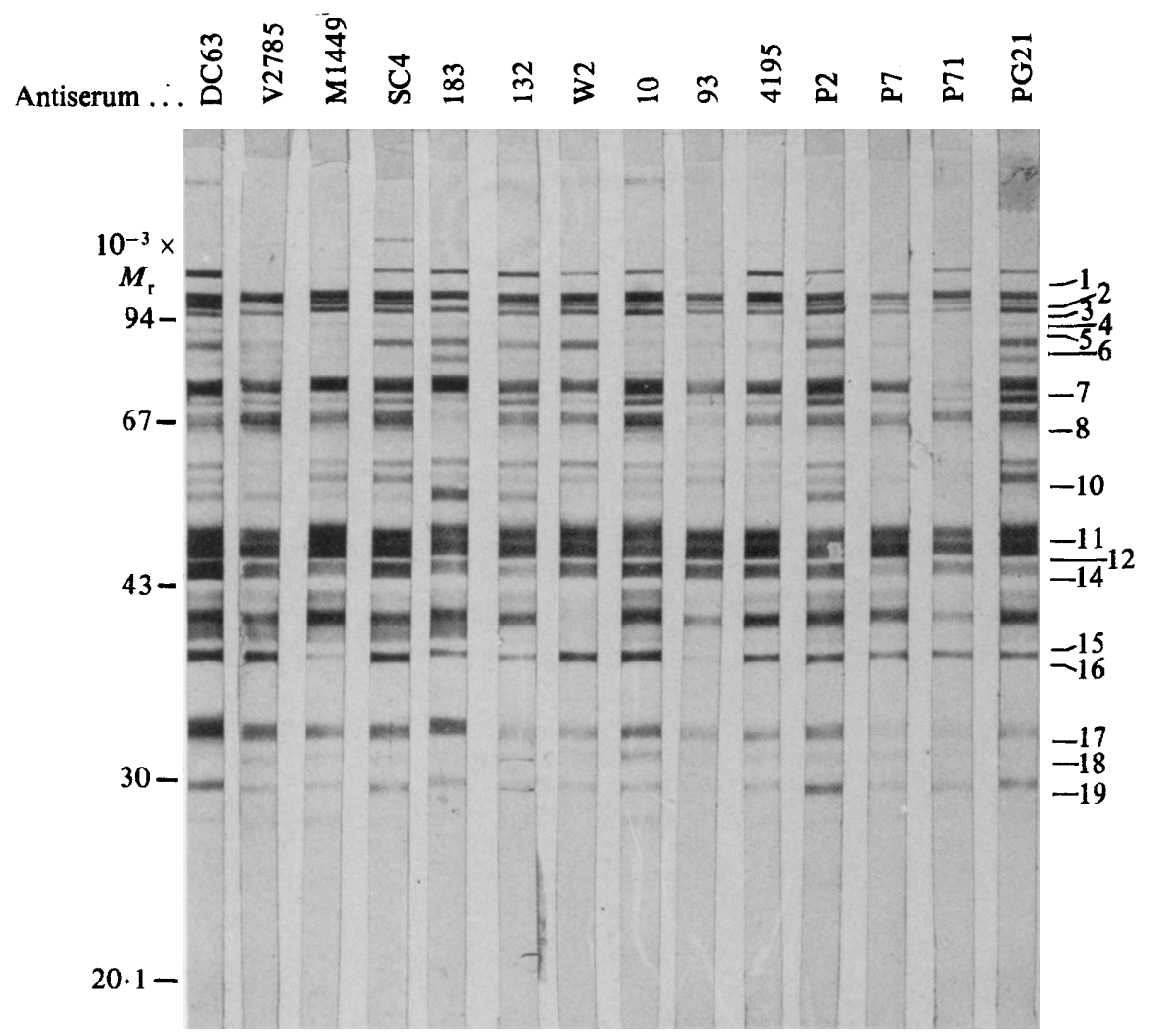

Fig. 5. Immunological identification of antigens of $M$. hominis strain DC63 after blot transfer using rabbit antisera against $14 \mathrm{M}$. hominis strains. Some of the 22 protein bands selected from the SDS-gel (Fig. 3) and which were immunologically detected are shown to the right. The method used was according to the Bio-Rad standard procedure. $M_{\mathrm{r}}$ standards as in Fig. 3.

Table 4. Results of an immunoblotting analysis of $14 \mathrm{M}$. hominis strains

Nineteen protein antigens found in SDS-PAGE (see Figs 3-5) were selected for this investigation.

$\begin{array}{ccc}\text { Antigen } & M_{\mathrm{r}} & \begin{array}{c}\text { No. of strains } \\ \text { in which antigen } \\ \text { found in SDS-PAGE }\end{array} \\ 1 & 102000 & 12 \\ 2 & 96000 & \text { all } \\ 3 & 94000 & \text { all } \\ 4 & 92000 & 13 \\ 5 & 88000 & \text { all } \\ 6 & 83000 & \text { all } \\ 7 & 78000 & 8 \\ 8 & 68000 & \text { all } \\ 9 & 58000 & 11 \\ 10 & 57000 & 9 \\ 11 & 49000 & \text { all } \\ 12 & 47000 & \text { all } \\ 13 & 44000 & 10 \\ 14 & 43000 & 4 \\ 15 & 39000 & \text { all } \\ 16 & 38000 & \text { all } \\ 17 & 33000 & \text { all } \\ 18 & 31000 & \text { all } \\ 19 & 30000 & \text { all }\end{array}$

Strains in which antigen not found

V2785, PG21

4195

DC63, V2785, W2, 10, 93, 4195

DC63, SC4, 132

V2785, M1449, 183, W2, 10

DC63, V2785, SC4, 132

All except DC63, V2785, SC4, 132
Antigens detected by all 14 antisera 
blue staining of unlabelled proteins, greatly exceeds the numbers obtained in earlier studies (Razin, 1968; Hollingdale \& Lemcke, 1970); this increase in resolution reflects technical improvements in the PAGE technique. Furthermore, the bands detected in our immunoblot assay were much more numerous than those found by Brown et al. (1983) in their Western blot analysis of the seven strains of Lin \& Kass (1974) with an M. hominis PG21 rabbit antiserum. As that serum, in contrast to our hyperimmune sera, was produced by immunization with (presumably relatively intact) whole cells, the antigens detected by Brown et al. (1983) were probably mainly confined to the cell surface. No other studies of $M$. hominis by $2 \mathrm{D}$ gel electrophoresis are available for comparison with ours.

In general, the results of our comparative assay of 14 selected strains of $M$. hominis confirms and extends previous observations by other workers of a relatively high degree of intraspecific heterogeneity. The finding of apparently more pronounced similarities between the strains when tested by SDS-PAGE (range of congruence 76-99\%), as compared to the results of $2 \mathrm{D}$ gel electrophoresis (calculated homology $41-72 \%$ ) is not surprising: since $2 \mathrm{D}$ gel electrophoresis separates individual bands according to both their isoelectric point and their $M_{\mathrm{r}}$, this method is likely to provide a higher degree of resolution.

A study by Barile et al. (1983) indicated that strains of $M$. hominis isolated from the same source, such as post-partum blood culture, the urogenital tract, or cell cultures, have very high genomic homology, strains from each source falling into clusters. Although the 14 strains we examined were derived from varied sources (Table 1), the number of strains of identical origin was in most cases not sufficiently high to allow any valid conclusions. Only three strains (P2, P7 and P71) isolated from one site (the upper urinary tract of patients with acute pyelonephritis) appeared to be particularly similar, although not greatly different from other strains. It is worth mentioning that the seven strains isolated from the lower urogenital tract (Table 1) were not found to be more closely related to each other than to strains isolated from other locations. This apparent discrepancy between our findings and those reported by Barile et al. (1983) may indicate a lack of close correlation between nucleic acid homology and antigenic properties; it might also be explained, at least in part, by the antigenic drift that may occur during repeated passages of laboratory strains, a phenomenon that makes it difficult to compare data from different laboratories (M. F. Barile, personal communication).

The implications of the heterogeneity of $M$. hominis were discussed recently by Freundt (1983), with particular regard to the consequences it may have for identification of new isolates and for serodiagnosis of $M$. hominis infections, and to taxonomic considerations. As to the taxonomic status of $M$. hominis, the tentative proposal by Lin \& Kass (1974) and Lin et al. (1975) to recognize at least seven serovars of the species has never received general acceptance. The observations presented in this paper do not, in our opinion, provide any additional evidence in support of that proposal.

We wish to thank Ruth Nielsen for expert technical help. This research was supported by a grant from The Danish Medical Research Council.

\section{REFERENCES}

Andersen, H., Christiansen, G. \& Christiansen, C. (1984). Electrophoretic analysis of proteins from Mycoplasma capricolum and related serotypes using extracts from intact cells and from minicells containing cloned mycoplasma DNA. Journal of General Microbiology 130, 1409-1418.

ARCher, D. B., Rodwell, A. W. \& Rodwell, E. S. (1978). The nature and location of Acholeplasma laidlawii membrane proteins investigated by twodimensional gel electrophoresis. Biochimica et biophysica acta 513, 268-283.

Barile, M. F., Grabowski, M. W., Stephens, E. B., O'Brien, S. J., Simonson, J. M., IzUmikawa, K., Chandler, D. K. F., Taylor-Robinson, D. \& Tully, J. G. (1983). Mycoplasma hominis-tissue cell interactions: a review with new observations on phenotypic and genotypic properties. Sexually Transmitted Diseases 10, no. 4, Suppl., 345-354.

Bjerrum, O. J., LARSEN, K. P. \& Wilken, M. (1983). Some recent developments of the electroimmunochemical analysis of membrane proteins. Application of Zwittergent, Triton X-114 and Western blotting technique. In Modern Methods in Protein Chemistry, pp. 79-134. Edited by H. Tschesche. Berlin \& New York: de Gruyter.

Brown, M. B., Minion, F. C., DAVIS, J. K., Pritchard, D. G. \& Cassell, G. H. (1983). Antigens of Mycoplasma hominis. Sexually Transmitted Diseases 10. no. 4, Suppl., 247-255.

Ernø, H., Jurmanova, K. \& Leach, R. H. (1973). 
Bovine mycoplasmas: a serological study by the metabolic inhibition test. Acta veterinaria scandinavica 14, 511-523.

FREUNDT, E. A. (1983). Mycoplasma hominis: historical outline and taxonomy. Sexually Transmitted Diseases 10, no. 4, Suppl. 226-229.

Fris, H., Plesner, A., Scheibel, J., Justesen, T. \& LIND, K. (1983). Mycoplasma hominis septicaemia. British Medical Journal 286, 2013-2014.

HAYfliCK, L. (1965). Tissue cultures and mycoplasmas. Texas Reports on Biology and Medicine 23, Suppl. 1, 285-303.

Hollingdale, M. R. \& Lemcke, R. M. (1969). The antigens of Mycoplasma hominis. Journal of Hygiene 67, 585-602.

Hollingdale, M. R. \& Lemcke, R. M. (1970). Antigenic differences within the species Mycoplasma hominis. Journal of Hygiene 68, 469-477.

INTERNATIONAL COMMITTEE ON SYSTEMATIC BACTERIOLOGY SUBCOMMITTEE ON THE TAXONOMY OF MOLLICUTES (1979). Proposal of minimal standards for descriptions of new species of the class Mollicutes. International Journal of Systematic Bacteriology 29, $172-180$.

LAEMMLI, U. K. (1970). Cleavage of structural proteins during the assembly of the head of bacteriophage T4 Nature, London 227, 680-685.

LeE, Y.-H., Nersasian, R. R., Lan, N. K., MCDONALD, A. \& MCCoRmaCK, W. M. (1971). Wound infection with Mycoplasma hominis. Journal of the American Medical Association 218, 252-253.

LIN, J.-S. \& KASS, E. H. (1974). Serological reactions of Mycoplasma hominis: differences among mycoplasmacidal, metabolic inhibition and growth agglutination tests. Infection and Immunity 10, 535-540.

LiN, J.-S. L., Alpert, S. \& RADNEY, K. M. (1975). Combined type-specific antisera in the identification of Mycoplasma hominis. Journal of Infectious Diseases 131, 727-730.

Mouches, C., Vignault, J. C., Tully, J. G., Whitcomb, R. F. \& Bove, J. M. (1979). Characterization of spiroplasmas by one- and two-dimensional protein analysis on polyacrylamide slab gels. Current Microbiology 2, 69-74.

Nascimento, E. R., Nascimento, M. G. F., Freundt, E. A. \& ANDERSEN, H. (1986). Isolation of Mycoplasma mycoides from outbreaks of caprine mycoplasmosis in Brazil. British Veterinary Journal 142, 246-257.

Nicol, C. S. \& EDWARD, D. G. (1953). Role of organisms of the pleuropneumonia group in human genital infections. British Journal of Venereal Diseases 29, 141-150.

O'Farrell, P. H. (1975). High-resolution two-dimensional electrophoresis of proteins. Journal of Biological Chemistry 250, 4007-4021.

PlatT, R., WARREN, J. W., EdELIN, K. C., LiN, J.-S., Rosen, B. \& MCCORMICK, W. M. (1980). Infection with Mycoplasma hominis in postpartum fever. Lancet 2, 1217-1221.

Purcell, R. H., Wong, D., Chanock, R. M., TAYLOR-Robinson, D., CANChola, J. \& VAldesuso, J. (1967). Significance of antibody to mycoplasma as measured by metabolic inhibition techniques. Annals of the New York Academy of Sciences 143, 664-675.

RAZIN, S. (1968). Mycoplasma taxonomy studied by electrophoresis of cell proteins. Journal of Bacteriology 96, 687-694.

RoDWELl, A. W. (1982). The protein fingerprints of mycoplasmas. Review of Infectious Diseases 1 (Supplement, May-June), S8-S17.

Rodwell, A. W. \& Rodwell, E. S. (1978). Relationships between strains of Mycoplasma mycoides subspecies mycoides and capri studied by twodimensional gel electrophoresis of cell proteins. Journal of General Microbiology 109, 259-263.

Somerson, N. L., Reich, P. R., Walls, B. E., Chanock, R. M. \& Weismann, S. M. (1966). Genetic differentiation by nucleic acid homology. II. Genotypic variations within two Mycoplasma species. Journal of Bacteriology 92, 311-317.

TAYLOR-RoBinson, D. \& MCCORMACK, W. M. (1980). The genital mycoplasmas. New England Journal of Medicine 302, 1003-1009; 1063-1067.

TAYLOR-ROBINSON, D., SOMERSON, N. L., TURnER, H. C. \& Chanock, R. M. (1963). Serological relationships among human mycoplasmas as shown by complement-fixation and gel diffusion. Journal of Bacteriology 85, 1261-1273.

Taylor-Robinson, D., Ludvig, W. M., Purcell, R. H., Mufson, M. A. \& Chanock, R. M. (1965). Significance of antibody to Mycoplasma hominis type 1 , as measured by indirect haemagglutination. Proceedings of the Society for Experimental Biology and Medicine 118, 1073-1083.

Thomsen, A. C. (1978). Mycoplasmas in human pyelonephritis: demonstration of antibodies in serum and urine. Journal of Clinical Microbiology 8, 197-202. 